\title{
Changes of the agricultural staff potential in the transition to digital agriculture
}

\author{
Asiya K. Subaeva ${ }^{1}$, Marat M. Nizamutdinov ${ }^{2, *}$, and Leysan M. Mavlieva ${ }^{2}$ \\ ${ }^{1}$ Russian State Agrarian University - Moscow Agricultural Academy named after K. A. Timiryazev, 127550 Moscow, Russia \\ ${ }^{2}$ Kazan State Agrarian University, 420015 Kazan, Russia
}

\begin{abstract}
The article is devoted to the study of agrarian personnel potential in the digitalization of agriculture. The article provides information on the level of implementation of the digital economy in the agricultural sector; aspects of the introduction of digital agriculture into production are revealed; the level of education of the personnel potential of rural workers is analyzed; the prospects of digitalization of the machine and tractor fleet of the agro-industrial complex are revealed.
\end{abstract}

\section{Introduction}

There are many definitions of the digital economy. Let us turn to the definition of the digital economy, which was proposed by the World Bank since this definition is the most acceptable from our point of view for understanding. The World Bank proposed to understand the digital economy as a system of economic, social, and cultural relations based on the use of digital information and communication technologies. This definition emphasizes such aspects of the digital economy that connect the digital economy with a new round in the machine industry, one of the directions of which is the creation of artificial intelligence technology.

They started talking about the digital economy after the May Decree of the President dated 05/07/2018 No. 204 (pp. "b," p. 11), wherein order to implement breakthrough scientific, technological and socio- economic development of the Russian Federation, the digital economy has become one of the directions.

The project "Personnel for the Digital Economy" is one of six federal projects that is dedicated to the provision of training highly qualified personnel for the digital economy, the responsibility for the implementation of which is vested in the Ministry of Higher Education and Science of the Russian Federation. One of the indicators of the achievement of the task "Digital platforms for the state, citizens, and business" should be the use of spatial data in urban and agricultural sectors.

These circumstances make it necessary to change the agricultural sector since its growth in the digital economy requires many transformations in the agricultural sector. The direction of changes in the agricultural industry under the influence of the digital economy is presented in Figure 1.

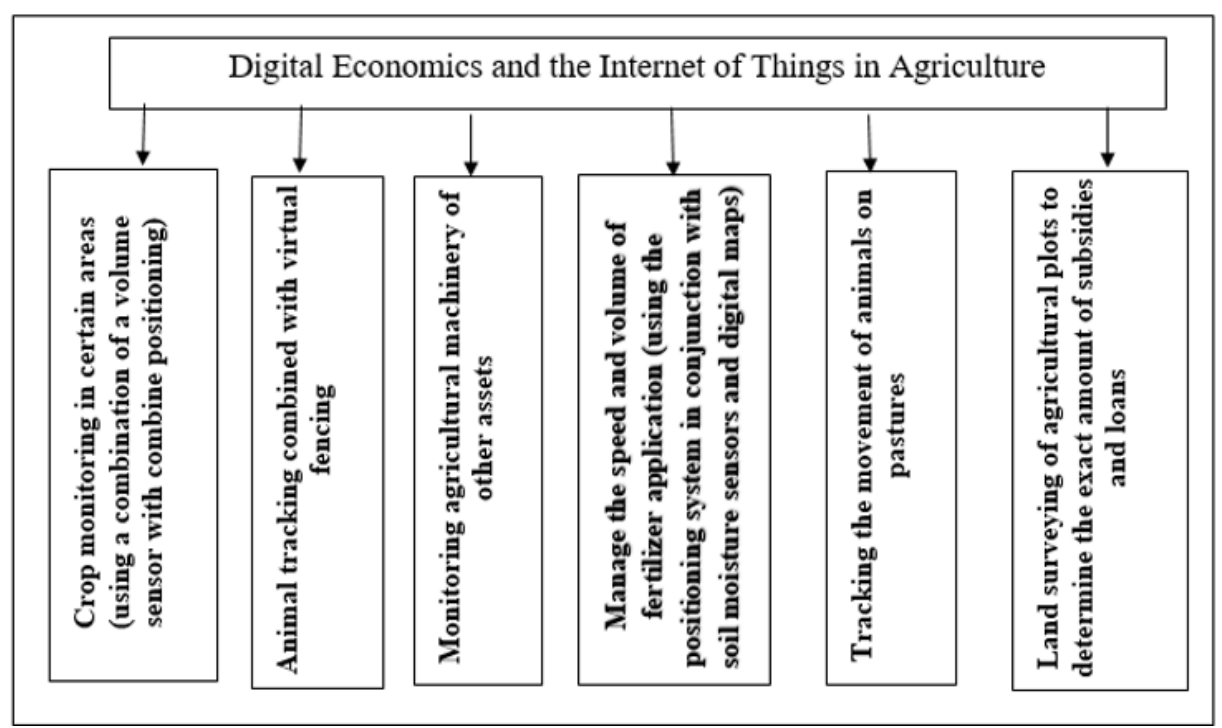

Fig. 1. The digital economy and the Internet of things in agriculture.

\footnotetext{
* Corresponding author: marat181@ rambler.ru
} 


\section{Methods}

The digital transformation of agriculture is a change in three directions. The first area of change is new business models (offering innovative products to customers and maintaining the competitiveness of enterprises). The second area of change is business infrastructure (optimizing and improving the efficiency of infrastructure and equipment). The third area of change is people and their capabilities.

A part of Russian enterprises among them and agricultural enterprises have already begun the digital transformation of production. However, at the same time, most enterprises do not have a comprehensive digitalization program, which leads to the fact that their activities are reduced to different digital solutions. At the same time, the incomplete availability of infrastructure processes is holding back digitalization. But the most important constraining factor is cultural restrictions and lack of education, including the conservatism of workers and their reluctance to change "what works like that", fear of future reduction due to digitalization, a lot of new information, fear of responsibility, lack of project experience for employees, clash of different cultures.

The main goal of digitalization is to increase productivity and reduce costs. So $51 \%$ of Russian companies expect a return on investment in digitalization within 2 years [1]. Only $16 \%$ of Russian companies have entered the positions of managers of digitalization programs, and another $44 \%$ of companies have allocated responsibilities among existing top managers. $34 \%$ of companies formed professional centers of competence in digital technology. At the same time, companies seek to hire full-time specialists in the field, and flexible forms of employment are not welcome.

Thus, the main ones in the digital economy are people who, under its influence, change the level of their education and, thereby, the labor market. The development of the digital economy leads to the disappearance of many professions in agriculture.

The criteria for developing training programs for "promising" professions in agriculture should be:

- the connection of professions with the advent of new technologies in demand in the digital economy;

- the critical importance of the profession for the agricultural industry;

- attractiveness for the new generation I-GEN;

- mass character.

In this case, the possibility of automation of each process is individual [2], so if the processes of agricultural production have the most significant potential for the implementation of $60-73 \%$, then the process of digitalization of education is less than $30 \%$. Robots cannot replace creative and creative employees, their emotional intelligence, the flexibility of thinking, persuasion, adaptability, time management. Only $5 \%$ of specialties can be fully automated, $30 \%$ can be $60 \%$, $60 \%$ can only $30 \%$. As a result of digitalization, workers are able to do more work freed from routine [2].

According to the World Economic Forum 2018, people who have lost their jobs are not able to take new jobs; the situation on the labor market is such that for $54 \%$ of employees, it is necessary to retrain or upgrade their skills and develop new competencies. In this regard, in Russia, many companies plan to revise the requirements for personnel, their competencies, and training methods [3].

So in connection with the advent of new technologies, $86 \%$ of companies plan to hire new employees with new competencies, automate the same number of jobs and reduce staff. $74 \%$ of companies plan to hire new temporary employees. $68 \%$ of companies plan to retrain existing employees at the workplace. $62 \%$ of companies plan to outsource functions to external contractors. $59 \%$ of companies plan to hire freelancers. $54 \%$ of companies plan to reduce workers who do not have the required competencies $[3,4]$.

A number of changes are observed in the organization of labor both in agriculture and in other sectors: personnel labor becomes more creative; new forms of interaction are added; informal, remotely working groups are created, including employees of different departments; project work is activated; digital centers are created competencies; workspaces are changing; the style of clothing is becoming more comfortable for work; a flexible schedule is being introduced; comfortable working conditions are being created; hackathons and meetups are held.

Hackathon is a forum for software developers where work is carried out together to solve a problem, for example, an application.

Meetup is a meeting of like-minded people to discuss specific issues in an informal setting.

Two methods (hackathons and meetups) are the solution of various tasks of digital development of organizations, as well as the search and attraction of talents. A channel for attracting external ideas through invited "from the market" developers, a way to attract and motivate internal resources of the company, the ability to solve non-standard tasks that they would never have been invited to in "ordinary" life, the opportunity to get to know each other's competencies and personal qualities which in other educational and communicative practices would remain unclaimed and unused.

The modern educational process does not keep pace with the needs of the market; it is not ready to quickly respond to the needs of digitalization. Therefore, enterprises are forced to prepare them on their own using the methods of hackathons and meetups.

Only professional training is no longer enough to create regional platforms for network interaction, interregional centers of competence. It should be noted that agriculture is one of the sectors with a high potential for digitalization, but a slow transition to mass transformations, which allow providing training to the competencies of the digital economy of workers in the agrarian industry as soon as possible. In agriculture, the main thing remains the importance of substantiating investment decisions, rather than the race for technology for the sake of technology, to which some experts are trying to tie the assessment of the digitalization level of enterprises and regions, ignoring many factors, for 
example, taking into account crop forecasts in regions with natural factors.

In connection with the previous, it is necessary to assess the personnel potential of the farmers of the present and future Republic of Tatarstan, which allows us to study the development of trends in the division of labor within their total labor force (Table 1).

For the analyzed period, there is a tendency to decrease in the number of workers in labor collectives of agricultural organizations. The supply of labor in the agricultural segment of the market is often formed by training workers and specialists in professional lyceums, colleges, and higher educational institutions. Analysis of the table shows that the number of agricultural workers in the Republic of Tatarstan has a steady tendency to decrease. So, for the period from 2011 to 2017, the total number of workers in agricultural organizations decreased by 19.8 thousand people $(27.9 \%)$, and workers employed directly in agricultural production by 18.8 thousand people $(28,3 \%)$, with a positive trend in the development of the agricultural industry in the Republic of Tatarstan.

Table 1. The dynamics of the number of employees of agricultural organizations of the Republic of Tatarstan, thousand people

\begin{tabular}{|c|c|c|c|c|c|c|c|c|c|c|}
\hline \multirow[t]{2}{*}{ Indicators } & \multirow[t]{2}{*}{2011} & \multirow[t]{2}{*}{2012} & \multirow[t]{2}{*}{2013} & \multirow[t]{2}{*}{2014} & \multirow[t]{2}{*}{2015} & \multirow[t]{2}{*}{2016} & \multirow[t]{2}{*}{2017} & \multirow{2}{*}{$\begin{array}{c}2017 . \\
\text { in } \% \text { to } 2011\end{array}$} & \multicolumn{2}{|c|}{ Structure. $\%$} \\
\hline & & & & & & & & & 2011 & 2017 \\
\hline In the organization - total & 71.1 & 66.0 & 62.8 & 59.3 & 57.9 & 58.4 & 51.3 & 72.1 & 100.0 & 100.0 \\
\hline $\begin{array}{l}\text { Including } \\
\text { Employed in agricultural } \\
\text { production - total }\end{array}$ & 66.6 & 62.0 & 58.9 & 56.3 & 53.6 & 54.0 & 47.8 & 71.7 & 93.6 & 93.1 \\
\hline Including permanent workers & 51.5 & 48.1 & 45.8 & 38.2 & 41.1 & 42.6 & 36.7 & 71.2 & 72.4 & 71.5 \\
\hline Including: Tractor drivers & 11.0 & 10.1 & 9.4 & 9.8 & 9.3 & 9.6 & 8.8 & 80.0 & 15.4 & 17.1 \\
\hline $\begin{array}{l}\text { Milking machine operators. } \\
\text { Milkers }\end{array}$ & 7.3 & 6.7 & 6.4 & 6.1 & 5.9 & 5.9 & 5.0 & 68.5 & 10.2 & 9.7 \\
\hline Cattle workers & 9.2 & 8.3 & 8.1 & 7.8 & 7.2 & 7.1 & 5.9 & 64.1 & 12.9 & 11.5 \\
\hline Pig workers & 1.7 & 1.4 & 1.1 & 0.9 & 0.7 & 0.6 & 0.5 & 29.4 & 2.4 & 0.9 \\
\hline Sheep and goat breeding workers & 0.1 & 0.08 & 0.06 & 0.06 & 0.05 & 0.06 & 0.05 & 50.0 & 0.1 & 0.1 \\
\hline Poultry workers & 1.9 & 2.04 & 2.1 & 2.1 & 2.0 & 2.1 & 2.2 & 115.7 & 2.6 & 4.2 \\
\hline Equine workers & 0.3 & 0.2 & 0.2 & 0.2 & 0.2 & 0.2 & 0.1 & 33.3 & 0.4 & 0.2 \\
\hline Seasonal workers & 3.9 & 3.4 & 2.9 & 2.8 & 2.7 & 2.3 & 2.4 & 61.5 & 5.4 & 4.6 \\
\hline Employees & 11.0 & 10.4 & 10.1 & 9.9 & 9.7 & 9.0 & 8.6 & 78.1 & 15.4 & 16.7 \\
\hline Including: Executives & 2.5 & 2.4 & 2.2 & 2.2 & 2.2 & 2.2 & 1.9 & 76.0 & 3.5 & 3.7 \\
\hline Specialists & 6.9 & 6.4 & 6.3 & 6.3 & 6.2 & 5.7 & 5.7 & 82.6 & 9.7 & 11.1 \\
\hline Industrial workers & 2.7 & 2.6 & 2.4 & 2.4 & 2.4 & 2.5 & 2.5 & 92.5 & 3.8 & 4.8 \\
\hline $\begin{array}{l}\text { Housing and communal services } \\
\text { workers }\end{array}$ & 0.02 & 0.02 & 0.02 & 0.03 & 0.06 & 0.06 & 0.02 & 100.0 & 0.02 & 0.03 \\
\hline Trade workers & 1.2 & 0.8 & 0.9 & 0.9 & 1.08 & 1.1 & 0.5 & 41.6 & 1.7 & 0.9 \\
\hline Construction workers & 0.5 & 0.4 & 0.4 & 0.3 & 0.3 & 0.3 & 0.2 & 40.0 & 0.7 & 0.4 \\
\hline Workers of other activities & - & 0.007 & 0.01 & 0.2 & 0.3 & 0.3 & 0.2 & - & - & 0.4 \\
\hline
\end{tabular}

*The authors calculate the indicators according to the Republic of Tatarstan. We want to draw attention to the situation of workers of such categories as tractor drivers, machine operators, and machine milking operators, whose number during the analyzed period decreased by 2.2 and 2.3 thousand people, respectively [4-8]. Along with the reduction in the number of agricultural workers, their structure is changing. During the study period, the proportion of workers in the total number of workers is reduced. Although the proportion of tractor drivers has increased by $1.7 \%$, while their number has decreased by $20 \%$. This situation is primarily due to positive trends in the development of the crop sector in the region - a feature of structural changes in the comparison of permanent and temporary workers. At the same time, there is a tendency to increase in the share of specialists, which increased by $1.4 \%$, which may be a decisive factor, indicating, for example, the growing role of intellectual labor in agricultural production [6].

Studies of the level of education of agricultural workers in the Republic of Tatarstan showed a specific positive trend in the dynamics and structure of labor demand in the level of education of agricultural workers in the industry as a whole for 2009-2017. Moreover, an increase in the share of workers with higher and secondary specialized education (Fig. 2).

According to data in 2017, compared with 2009, the proportion of managers with higher education increased by 2.4 percentage points. A similar situation exists in the category of specialists in personnel of mass professions, the proportion of which with higher education grew by 1.9 percentage points.

In general, $44.4 \%$ of managers and specialists in agricultural organizations have higher education. However, the lack of professional education in $20 \%$ of agricultural workers amid the intensive development of scientific and technological progress is alarming.

Machine operators and drivers have a higher qualification level among professional groups of workers. An analysis of the personnel situation in agricultural organizations of the Republic of Tatarstan shows that in 2017, the proportion of machine operators of the I and II class was $62 \%$ of their total number, drivers $-60 \%$.

However, the supply of agricultural organizations with qualified workers and specialists is not the same, since there is a professional-qualification imbalance in supply and demand. Besides, a decrease in demand is simultaneously accompanied by a shortage of supply of qualified personnel and their weak localization. $[9,10]$.

According to the results of data analysis (Fig. 2), it can be argued that workers with secondary vocational 
education have the largest share in the scale of distribution of the number of employees by the level of education in agriculture.

The percentage of workers with secondary education in agriculture is more than $30 \%$, which means that the main emphasis in training in digital technologies should be given to this group, especially the engineering staff.

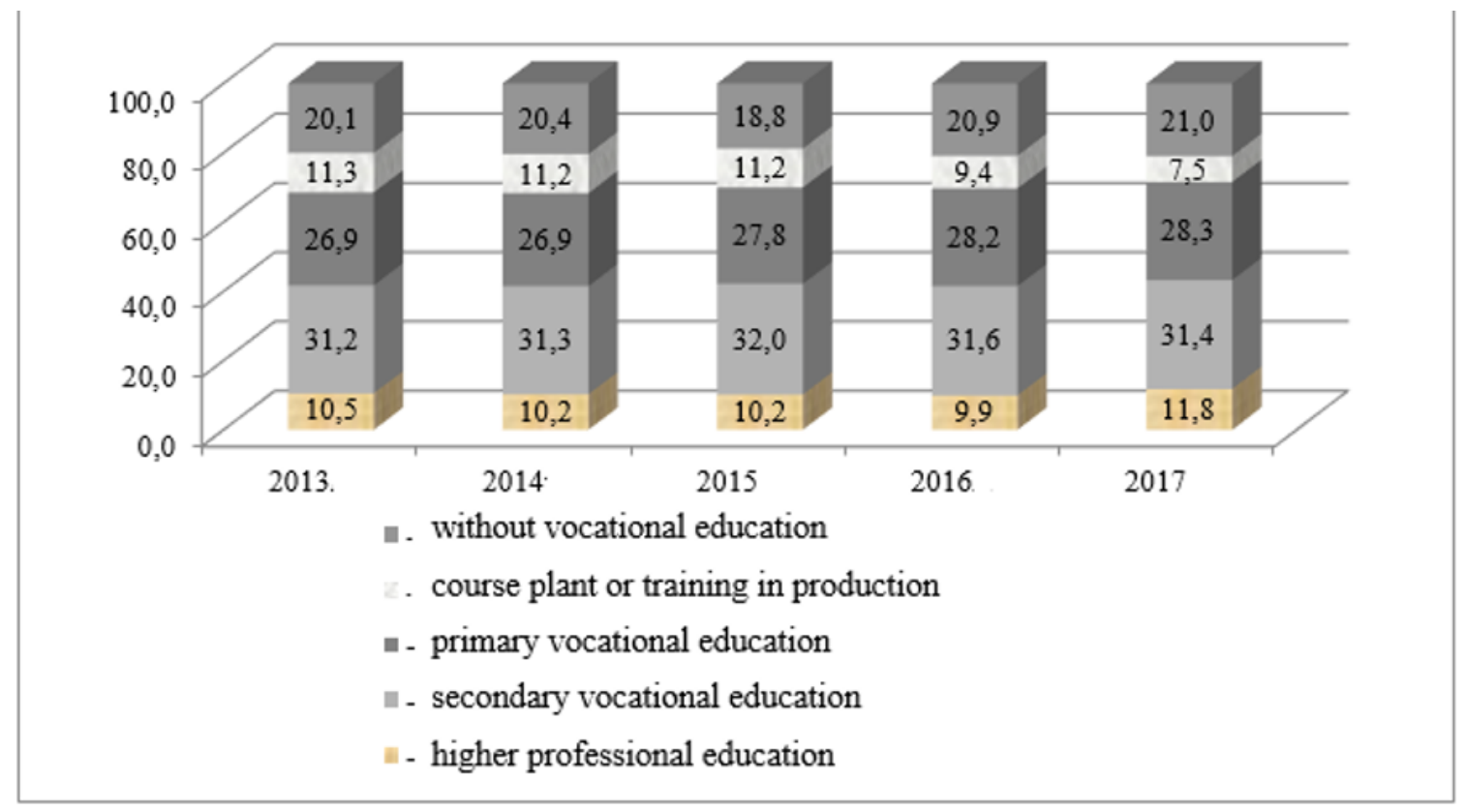

Fig. 2. Distribution of the number of employees by level of education in agriculture (\% of total)

* Compiled according to the data of Tatarstan

\section{Results}

In this regard, we are proposing a project to create an agrarian educational network platform "Advanced training and retraining of personnel in the digital transformation of agriculture." The concept of "network" is primarily interconnected with the concept of cluster interaction. Because the Republic of Tatarstan has cluster development, it is necessary to propose a clusternetwork interaction mechanism to increase its development efficiency. The distinctive cluster feature from a cluster-network association is an integrated resource, which allows increasing the speed of interaction of all its components. New information technologies with a new force made it possible to discover the essence of network form through the formation of the material base for the development of network space. New interactions create new relationships with stable development [4].

The cluster-network approach allows you to expand the external influence of the cluster potential and rise to the inter-regional level of interaction, enter a new format of management style, the level of network activity, and realize other opportunities for the development of the rural economy. Given a weak resource base, participants in the cluster-network platform are given additional opportunities for development potential as a result of the interaction of the subjects of these systems.

At this stage, not all clusters yet have a clusternetwork form, and therefore, we propose the creation of a cluster-network platform "Advanced training and retraining of personnel in the digital transformation of agriculture" in the educational cluster of the agroindustrial complex of the Republic of Tatarstan.

The goal of the project is to develop and implement a model for transforming the personnel of the agrarian industry into digital agriculture, based on the principle of continuity, network interaction, social responsibility of business and education.

The relevance of the project is determined by the need of the labor market for the training of highly qualified engineering and technical personnel with digital competencies that allow flexible and quick response to production needs (creativity, initiative, learning ability, motivation for self-development, analytical skills and working with big data, multitasking, programming, transdisciplinarity). Teachers of agricultural educational institutions at different levels of education are not aware of and do not realize the continuity of programs in the context of labor market needs; there is a mismatch of teaching methods and technologies.

For students and teachers, there is no way to enrich social experience in the workplace through classes in laboratories, master classes of leading specialist engineers. Retraining programs for students of continuing education courses that meet the requirements of the "digital agriculture" competency have not been developed.

The innovation of the project lies in the implementation of the dual model of advanced training and professional training based on the principles of continuity, orientation practices, network interaction. 
The innovation of the project lies in the implementation of the dual model of advanced training and professional training based on the principles of continuity, orientation practices, network interaction. This project involves the development of technology, including the development by the student of the program of various professional roles (moderator, researcher, project manager, tutor, and others). The forms of the educational process are social and industrial practice, a creative workshop, an internship on issues of interest.

\section{Conclusion}

In accordance with the departmental project of the Ministry of Agriculture of the Russian Federation "Digital Agriculture", a set of measures aimed at digitalizing the agricultural sector leads to an increase in labor productivity in 2019 to $105 \%$, in 2020 to $150 \%$, in 2021 to $200 \%$, which is a particular proportion implementation of these proposals may contribute.

\section{References}

1. Digital technologies in Russian companies $K P M G$ (2019) Retrieved from: https://assets.kpmg/ content/dam/kpmg/ru/pdf/2019/01/ru-ru-digitaltechnologies-in-russian-companies.pdf

2. A future that works: automation. Employment. Productivity (2017) Retrieved from: https://www.mckinsey.com/ /media/mckinsey/featu red \%20insights/Digital \%20Disruption/Harnessing $\%$ 20automation \%20for \%20a \%20future \%20that $\% 20$ works/MGI-A-future-that-works-Executivesummary.ashx
3. World Economic Forum (FEA). The Future of Jobs Report 2018, Retrieved from: https://www.weforum. org/reports/the-future-of-jobs-report-2018

4. A.K. Subaeva, N.M. Yakushkin, M.M. Nizamutdinov, L.M. Mavlieva, Development of cooperation in the framework of strengthening the material and technical base of small forms of Economy, Revista Publicando, 4(12(1)), 568-577 (2017)

5. Statistical Yearbook Republic of Tatarstan-2017: coll. Terr. on the fed. state statistics service in the Republic of Tatarstan (Tatarstanstat, Kazan, 2017), $521 \mathrm{p}$.

6. Statistical Yearbook of the Republic of Tatarstan2017: coll. Terr. on the fed. state statistics service in the Republic of Tatarstan (Tatarstanstat, Kazan, 2017), $371 \mathrm{p}$.

7. M.A. Sysoev, T.I. Ashmarina et al., Innovations in the process of reproduction of agricultural machinery, monograph (Publishing house of Melitopol city printing house, Melitopol, 2013)

8. A.K. Subaeva, M.M. Nizamutdinov, Technical equipment of the village as a factor of the environment of direct and indirect impact on the financial results of the enterprise, Modern probl. of sci. and educat., 1 (2015) Retrieved from: http://www.science-education.ru/121-17727

9. Official site of Ministry of agriculture and food of the Republic of Tatarstan, Retrieved from: http://agro.tatarstan.ru/rus

10. GOST R 53056-2008 Agricultural Machinery. Methods of economic assessment, Retrieved from: http: / / www. docme. ru / doc/157881/gost-r-530562008-tehnika-sel. 